\title{
The Impact Of FDI Inflow On The Environment: A Case Of The Baltic-Black Sea Region Countries
}

\author{
https://doi.org/10.21272/sec.4(4).151-159.2020
}

Adisa Đonlagić, ORCID: https://orcid.org/0000-0001-5295-7400

Credit Risk Analyst, ProCredit Bank BiH, Bosnia and Herzegovina

Bogdan A. Moskalenko, ORCID: https://orcid.org/0000-0003-3972-1705

Business Client Advisor, Joint stock company "ProCredit Bank", Ukraine

\begin{abstract}
The article summarizes the arguments within the scientific challenge on improving approaches to estimate the environmental impact of FDI inflow on the economy. The main objective of the research is to systematize the existing statistical approaches to analyze whether and how the macroeconomic determinants could impact the environment in terms of greenhouse gas emission. Systematization of theoretical and methodological materials on solving the problem of choice of applying more or less stringent environmental regulations with addition to more efficient industrial technologies which are supposed to have a positive impact on the environment. The relevance of solving this problem is that inceptive of FDI inflow could provide the economy with resources which reduce pollution, create better conditions for workers and local citizens. On the other hand, FDI are not interested in investing in economies with strict environmental legislation. The methodical tools of the research are carried out in the following logical sequence: systematization of existing statistical methods panel data analysis; analysis of data that will be used in the estimation model and in further country environmental policy making process; application of fixed and random effects models in estimation of the environmental impact of FDI on analyzed data. The research methods combine in following dimensions: comparative analysis, regression analysis. The period from 1999 to 2018 was chosen as the research period. The objects of the research are foreign direct investment net inflows into the Baltic-Black Sea region countries` economies and their impact on its environment. The article presents the results of empirical analysis, which showed that FDI inflow has an impact on the environment, but it is severely limited by other more significant determinants. The pollution haven hypothesis in the Baltic-Black Sea trans-national region countries policy in attraction FDI has not been proved considering more strict high-standard environmental legislation in EU countries alongside with increase in GHG emission per capita. The results of the research can be useful within government policy making processes considering the aim to incentivize FDI inflow.
\end{abstract}

Keywords: country investment potential, environment, foreign direct investment, greenhouse gas emission, national economy.

JEL Classification: E22, E29, E44, E60, G31.

This work is licensed under a Creative Commons Attribution 4.0 International License.

Cite as: Đonlagić, A., Moskalenko, B.A. (2020 The Impact Of FDI Inflow On The Environment: A Case Of The Baltic-Black Sea Region Countries. SocioEconomic Challenges, 4(4), 151-159. https://doi.org/10.21272/sec.4(4).151-159.2020.

(C) The Authors, 2020. This article is published with open access at Sumy State University.

\section{Introduction}

The scientific discussion on the interrelation between foreign direct investment (FDI) inflow and the environment explores the subject on the following main branches: environmental conditions' effect of FDI flows; demand on FDI pushed by host economies' effects on their environmental standards; current international environmental 
problems and trends. The arguments for each ef statement differ within a specific economic sector of activity. In order to avoid misleading results, the majority of published works carried out so far was primarily focused on macroeconomic aspects of the nexus between FDI and pollution dynamics by investigating host economy data (Shahbaz et al., 2011; Liang, 2008).

Meanwhile, not much effort has been made to investigate the issue while considering the analyzed sector of the economy with the result that research does not provide a clear understanding of the phenomenon. FDI affects the environment, not as an isolated phenomenon, but interacts with a bunch of other linked determinants. Aiming this, research on this topic has been carried out by decomposing the environmental effects of FDI into explainable variables which ought to be relatively easily analyzed and forecasted.

The aim of this work is to investigate the linkage between FDI inflow and the environment empirically with the aim of verifying whether and how FDI impacts the host country environment. The result of this investigation will indicate the direction of government environmental policy: further incentivize FDI or restrict its inflow.

\section{Literature Review}

Within a few decades of active research, literature related to FDI and environmental issues on macroeconomic level has evolved over time. Despite this, recent ideas from around the globe are attempting to explain this phenomenon using a strong scientific theoretical foundation and statistical data. Discovering features of interrelation between FDI and the environment several scientific proposals of domestic and foreign scientists were analyzed.

The topic of FDI has been widely discussed in the literature over the years. Along with exploring the phenomenon of investment spillovers, researchers have sought to understand why resource owners decide to invest abroad, what are the drivers of international activity and why they choose a certain country to put their money into (Kok and Ersoy, 2009).

Governments all over the world make various actions to improve their competitiveness and also improve the investment attractiveness. It is believed, that the most valuable investment are those that create new jobs, increase gross domestic product (GDP), and develop infrastructure wherever they come to. On the one hand, countries want to incentivize FDI inflows, especially from technologically developed subjects. On the other hand, such an incentive could be performed by violating its own environment protection principles.

In regards to the specific case of environmental policy, the investors will most likely decide to enter a country where the existing environmental legislation allows it to develop its activity in certain pollution-intensive industries, to which the host-country government does not create legal barriers (Dunning, 2003).

According to that, FDI inflow will be influenced by the environmental regulation of the host country: multinational enterprises (MNEs) perceive a competitive disadvantage associated with countries or regions where such regulations exist (Erdogan, 2014). Thus, MNEs are going to invest in economies where the environmental laws are less binding. This principle is known as the pollution haven hypothesis $(\mathrm{PHH})$, which means that cost considerations are decisive when it comes to the choice of where to internationalize (Rezza, 2015).

Some authors (Cole et al., 2017) suggest that the effect of FDI on the host economy can either be positive or negative. First one comes when investors with advanced technologies decide to enter in a new market without competitors with the same level of technology. In this case, new production could reduce pollution, create better conditions for workers, local citizens etc. Negative consequences emerge when the investors enter a new country or region because they struggle to maintain a competitive business activity in the current one: new restrictions in home country's legislation, increasing costs of raw materials, aggressive competitors from undeveloped countries. Consequently, such an approach leads to pushing the pollution level inside the host country.

Among environmental issues studies there is a noticeable problem of environmental justice. According to this, risks of pollution increase and other environmental hazards are unequally distributed by races and classes (Mohai et al., 2009). It refers to moving toxic waste and other environmentally hazardous productions from developed 
wealthy regions to poor and developing ones, justifying it by the fact that people there are unable (or unwilling) to pay as much as a wealthier area for a cleaner environment.

In order to attract FDI the host country government could loosen up the local environmental regulations in the presence of a multinational firm which also is known as the "race to the bottom" strategy (Cole et al., 2017).

Another suggestion that explains FDI and environmental conditions nexus is related to the Kuznets curve. This hypothesis shows that as an economy develops, market forces first increase and then decrease pollution level. The development of environmental risks will follow an inverted "U" shape as it rises and then falls again with the increase of income per-capita index (Galbraith, 2007).

Wagner and Timmins (2009) identify pollution havens as an agglomeration of industrial production items, raised by MNEs' investment, which are focused on producing goods with many of the environmental pollutants. As follows, the pollution havens hypothesis $(\mathrm{PHH})$ is considered as relocation of potentially hazardous productions aiming the production costs optimization in order to obtain competitive advantages on international markets (Dong et al., 2012).

According to Hille (2018), the pollution haven principle has negative effects, not only on developing economies with less strict environmental protection legislation, but in more advanced countries in this matter as well. The climate policy-backed pollution haven influence concerning sectors is facing a rise in the shadow costs of emission relevant energy production.

Copeland and Taylor (2004) suggest that net imports of so-called non-clean products into highly regulated countries will rise because they choose a way of cleaner goods production despite some economic losses while avoiding more profitable activities. As follows, the pollution haven hypothesis demands that trade liberalization will support dirty industries allocation from developed countries with strict legislation to developing ones which pay less attention to environmental issues.

Porter (1999) concluded that developing countries are more affected by high-standard and low-standard environmental protection policies than developed countries, which are typically more concerned with having high environmental standards. In addition, the author highlights that in developing countries the social and economic reality does not allow government to work in frames of high-standards environmental legislation, given that their people want other legislative improvements, mostly related to economic prosperity.

The discussion on the environmental implication PHH and FDI-environment relation in general refers to applying more or less stringent environmental regulations with addition to more efficient industrial technologies which are supposed to have a positive impact on the environment. It shall be emphasized that the scale of this positive effect depends on the strength of the economy, its reserves and ability to generate needed investment resources. This process implies generation of more added value and, which is unavoidable, more pollution.

The environmental Kuznets curve (EKC) suggests that the solution to the pollution problem is economic growth. According to this statement, the relationship between environmental quality and economic development: tend to get worse as modern economic growth occurs until average income reaches a certain point over the course of development (Grossman, and Krueger, 1991).

Despite the existence of different views on the EKC (e.g. He and Richard 2010; Aslanidis and Iranzo 2009; Yaguchi et al. 2007; Stern 2004a, b; Perman and Stern 2003), many studies have concluded that the expectation of the decline of environmental quality, associated with economic growth effect, can be analyzed and estimated depending on the economic growth phase or point on time series data dynamic.

The aim of this work is to investigate the FDI-environment nexus empirically with the aim of verifying whether and how the FDI inflow entering the economy impacts its environment. The results should help us to understand which kind of government policy considering FDI attraction should be applied. 
SocioEconomic Challenges, Volume 4, Issue 4, 2020

ISSN (print) - 2520-6621, ISSN (online) - 2520-6214

\section{Methodology and research methods}

Research methods combine in following dimensions: comparative analysis, regression analysis of panel data. There are some data limitations that are discussed below. The data processing was done via STATA 14. Time series data related to greenhouse gas emission and FDI net inflow are represented in log values in order to use them suitably in software.

To investigate the FDI inflow and environment relationship, we have collected time series data related to greenhouse gas emission per capita and FDI inflow by sourcing statistical information from the databases of various international organizations. It contains data for 8 countries in the Baltic-Black Sea area, including Ukraine, for 20 years between 1999 and 2018.

The set of countries was chosen considering geographic position, economic and geopolitical interrelation which are important for government policy-making processes. The combination of geopolitics, ethnopolitics and biopolitics makes the Baltic-Black Sea trans-national region a source of inspiring policy practices, and, in the light of new security risks, a matter of increased concern all over Europe (Bogdanova and Makarychev, 2019).

The generalized formula that describes the relationship between environment (dependent variable) and a set of macroeconomic indexes (independent variables) considering both random and fixed effects models is as follows:

$Y_{i t}=\beta_{0}+X_{i t} \beta+Z_{i} \gamma+\alpha_{i}+\varepsilon_{i t}$,

where $Y_{i t}$ is greenhouse gas emission at year $\mathrm{t}, X_{i t}$ - observed and estimated time-variant factors, $Z_{i}-$ timeinvariant factors for random effect model, $\alpha_{i}$ - un-observed individual specific effect, $\varepsilon_{i t}$ - un-observed error term (residual), $\beta_{0}-$ constant term, $\beta, \gamma-$ constants.

The fixed effects regression model could be used with aim to reduce selection bias in the estimation of causal effects in panel data series by eliminating a significant portion of variation thought to contain confounding factors (Allison 2009; Wooldridge 2010). According to them, pooled OLS is employed while selecting a different sample for each year/month/period of the panel data. Fixed effects or random effects are employed in order to observe the same sample of countries, states, cities etc.

Comparatively to FE models, random effects models are used in panel data when we assume that there are no fixed effects (it allows for individual effects). Thus, the random effects model is a special case of the fixed effects model.

Related to our study, the impact of determinants of economic growth on environment could be presumed as the following formula:

$G H G P C_{i t}=\beta_{0}+\beta_{1} F D I_{i t}+\beta_{2} G D P_{i t}+\beta_{3} G F C F_{i t}+\beta_{4} E x p I m p_{i t}+\varepsilon_{i t}$,

where $i$ represents the cross-sectional units related to analysed eight Baltic-Black Sea region countries, $t-$ is the time units (1999-2018), $\varepsilon_{i t}$ - un-observed error term. A detailed description of the variables in our model is given in the following table (Table 1).

Table 1. Variable specification for model

\begin{tabular}{|c|l|l|}
\hline Variable & \multicolumn{1}{|c|}{ Description } & \multicolumn{1}{|c|}{ Data source } \\
\hline$G H G P C_{i t}$ & $\begin{array}{l}\text { Dependent variable. The amount of carbon dioxide and other greenhouse gases } \\
\text { emission from burning of fossil fuels measured in tons per capita. }\end{array}$ & $\begin{array}{l}\text { Our World in Data } \\
\text { (Oxford Martin } \\
\text { Programme). }\end{array}$ \\
\hline$G D P_{i t}$ & Natural logarithm for gross domestic product (USD per capita) & World Bank data \\
\hline$F D I_{i t}$ & Natural logarithm for FDI inflow (USD per capita) & World Bank data \\
\hline$G F C F_{i t}$ & Gross fixed capital formation (formerly gross domestic fixed investment), (\% of GDP) & World Bank data \\
\hline ExpImp $_{i t}$ & Export + import of goods and services (\% of GDP) & World Bank data \\
\hline
\end{tabular}

Sources: developed by the authors.

As can be seen, the model is built with the aim of identifying the direct and indirect effects of economic growth determinants and FDI inflow on greenhouse gas emission per capita variable. The contemporary consideration of 
macroeconomic determinants allows us to compute the cumulative (or total) effect which is achieved through the algebraic sum of the terms resulting from the partial derivative of the model equation with respect to independent variables.

A human capital quality effect is also considered in our model and was shown by estimation of two different determinants which refer to the relevance of the tertiary enrolment ratio in the considered economies and their unemployment ratio.

Analysed countries across the Baltic-Black Sea region are not similar considering their economic development level, socio-political determinants and industry structure. As follows, in order to conduct more statistically suitable results it is necessary to split analysed economies into groups:

1. EU countries: Estonia, Latvia, Lithuania, Poland.

2. Belarus (post-soviet country with authoritarian patterns in economy and socio-political infrastructure with high dependency from imported fossil fuel resources).

3. Moldova and Georgia (post-soviet economies without significant dependency on heavy industry on the way of reforms towards EU-standards).

4. Ukraine (post-soviet economy with resource-dependent heavy industry and poor institution infrastructure on the way of reforms towards EU-standards).

Endogeneity of the explanatory variables macroeconomic determinants has been controlled for in mainly three different ways: panel data combined with fixed effects or first differencing can be used to avoid an endogeneity bias. This is in particular frequently applied in gravity models estimation (Baier and Bergstrand 2007; Baier et al. 2014).

\section{Results}

In order to estimate the impact of FDI inflow and macroeconomic features on environment quality, a multicountry, sector-specific panel dataset is compiled for the years 1999-2018. The independent variables are determined on the basis of data provided by the World Bank Database (World Bank, 2019). Greenhouse gas emissions data are based on Our World in Data (Oxford Martin Programme on Global Development). The table below (Table 2) summarizes descriptive statistics for our variables.

Table 2. Summary statistics of the variables considered in models

\begin{tabular}{|c|c|c|c|c|c|c|c|}
\hline \multicolumn{2}{|c|}{ Variable } & \multirow{4}{*}{$\frac{\text { Mean }}{8.646866}$} & Stand.Dev & Min & Max & \multicolumn{2}{|c|}{ Observations } \\
\hline \multirow[t]{3}{*}{$\operatorname{LnGHGPC}$} & overall & & .5986902 & 7.468513 & 9.768126 & $\mathrm{~N}=$ & 160 \\
\hline & between & & .6138212 & 7.917847 & 9.598248 & $\mathrm{n}=$ & 8 \\
\hline & within & & .1633315 & 8.196558 & 9.165093 & $\mathrm{~T}=$ & 20 \\
\hline \multirow[t]{3}{*}{ LnGDP } & overall & \multirow[t]{3}{*}{3.680882} & .4341398 & 2.601648 & 4.366581 & $\mathrm{~N}=$ & 160 \\
\hline & between & & .3628618 & 3.19111 & 4.081148 & $\mathrm{n}=$ & 8 \\
\hline & within & & .2693375 & 3.091419 & 4.116522 & $\mathrm{~T}=$ & 20 \\
\hline \multirow[t]{3}{*}{ LnFDI } & overall & \multirow[t]{3}{*}{9.040871} & .6086497 & 7.578295 & 10.39848 & $\mathrm{~N}=$ & 158 \\
\hline & between & & .512618 & 8.284456 & 10.02452 & $\mathrm{n}=$ & 8 \\
\hline & within & & .3694783 & 7.916715 & 9.765046 & T-bar $=$ & 19.75 \\
\hline \multirow[t]{3}{*}{ ExpImp } & overall & \multirow[t]{3}{*}{109.605} & 25.79116 & 54.02154 & 169.4918 & $\mathrm{~N}=$ & 160 \\
\hline & between & & 21.02013 & 80.51519 & 151.4184 & $\mathrm{n}=$ & 8 \\
\hline & within & & 16.61739 & 62.6715 & 144.069 & $\mathrm{~T}=$ & 20 \\
\hline \multirow[t]{3}{*}{$G F C F$} & overall & \multirow[t]{3}{*}{23.72446} & 5.317396 & 13.54871 & 38.82708 & $\mathrm{~N}=$ & 160 \\
\hline & between & & 3.74898 & 18.82996 & 29.42314 & $\mathrm{n}=$ & 8 \\
\hline & within & & 3.9874 & 15.36145 & 34.80007 & $\mathrm{~T}=$ & 20 \\
\hline
\end{tabular}

Sources: developed by the authors based on WorldBank data, 1999-2018, annual report (2019); Our World in Data (2019).

First, we run OLS model estimations while considering robust standard errors for linear panel models to ensure an opportune correction for heteroskedasticity and autocorrelation. Table 3 shows the results for ordinary least squares (OLS) from Equations (1)-(2) based on variables in Table 1. 
The Breusch-Pagan/ Cook-Weisberg test helps to check the null hypothesis versus the alternative one. A null hypothesis is that where the error variances are all equal (homoscedasticity), whereas the alternative hypothesis states that the error variances are a multiplicative function of one or more variables (heteroscedasticity).

The existence of heteroskedasticity problems checked through the B-P/C-W test which generated a $\mathrm{X}^{2}(1)=0.03$ with a p-value $=0.8606$, which shows that the probability value of the chi-square statistic is more than 0.05 . Thus, the null hypothesis of constant variance could not be rejected at $5 \%$ level of significance. It implies the presence of homoscedasticity in the residuals.

The test for autocorrelation was performed by Breusch-Godfrey LM test for autocorrelation. According to that, the null hypothesis is non-existence of serial correlation between residuals. A chi-square $\left(\mathrm{X}^{2}\right)$ statistic is a measure of the difference between the observed and expected frequencies of the outcomes of a set of events or variables. The result showed a $\mathrm{X}^{2}(20)=115.024$ with a Prob $>\mathrm{chi}^{2}=0.0000$, rejecting the null hypothesis of non-existence of serial correlation.

This statement has been suggested from the very beginning, considering the economies of analysed countries are open and in relative dependency of each other and surrounding environment which makes them correlated to each other in case of macroeconomic indexes.

Regression analysis has shown that $\mathrm{R}^{2}=0.49$ which means a significant and positive impact of independent variables from Equations (2) on GHG emission per capita. Although, Prob $>\mathrm{F}=0.0000$ is less than 0.05, which indicates high level of statistical significance of the model.

The panel data estimation results of OLS model, as well as random effect model and fixed effects model are shown in Table 3.

Table 3. Panel data estimation results

\begin{tabular}{|c|c|c|c|c|}
\hline \multicolumn{2}{|c|}{ LnGHGPC(dependent variable) } & OLS & Fixed & Random \\
\hline \multirow[t]{2}{*}{$L n G D P$} & Coef. & .0163925 & $.1384428 * *$ & .1197288 \\
\hline & Stand. Err & .1021913 & .0681044 & .0805513 \\
\hline \multirow[t]{2}{*}{ LnFDI } & Coef. & $.6074679 *$ & .0723497 & $.1462744 * *$ \\
\hline & Stand. Err & .0715208 & .0523343 & .059256 \\
\hline \multirow[t]{2}{*}{ ExpImp } & Coef. & $.0108382 *$ & .0012159 & $.0020463 * *$ \\
\hline & Stand. Err & .001496 & .0007891 & .0041661 \\
\hline \multirow[t]{2}{*}{$G F C F$} & Coef. & .0020082 & .0022804 & .0012215 \\
\hline & Stand. Err & .0065792 & .0034902 & .0041661 \\
\hline \multirow[t]{2}{*}{ Constant } & Coef. & $1.857944 *$ & $7.295687 *$ & $6.630208^{*}$ \\
\hline & Stand. Err & .5858878 & .3138025 & .3867087 \\
\hline \multicolumn{2}{|c|}{ Number of observations } & 160 & 160 & 160 \\
\hline \multicolumn{2}{|c|}{ Number of groups } & - & 8 & 8 \\
\hline \multicolumn{2}{|c|}{ R-squared } & .5043 & Rho $=.9291$ & Rho $=.4184$ \\
\hline \multicolumn{2}{|c|}{ Adj. R-squared } & .4915 & & \\
\hline \multicolumn{2}{|c|}{$\begin{array}{l}\text { Wald-Chi }{ }^{2}(4) \\
\text { p-value }\end{array}$} & & \multicolumn{2}{|c|}{$\begin{array}{c}X^{2}(4)=10.37 \\
\text { Prob }>\text { chi }^{2}=.0347\end{array}$} \\
\hline
\end{tabular}

P-value: $*=0.000 ; * * \leq 0.05 ; * * * 0.10$.

Sources: developed by the authors.

In order to choose between fixed effects model and a random effects model we should run a Hausman test. The null hypothesis assumes the difference in coefficients is not systematic. The result (Table 3 ) shows a $\mathrm{X}^{2}(4)=$ 10.37 with a Prob $>\mathrm{chi}^{2}=0.0347$, so we reject the null hypothesis, which means we shall consider random effects model as a more appropriate one. As a result, we focus our attention on the results` interpretation achieved by the RE model.

Two-tail p-values test suggests that each coefficient is different from 0 . To reject this, the p-value has to be lower than $0.05(95 \%$, it is appropriate to choose an alpha of 0.10 as well), if this is the case then we could conclude that the variable has a significant influence on our dependent variable. 
The estimation of this model (Table 3) shows that two of the independent variables have p-values within statistically significant measures - LnFDI and ExpImp with p-values 0.014 and 0.035 respectively, thus we explain their meanings with more details furthermore.

Considering variable GDP, it is not correct to assume no relation between GDP dynamic and greenhouse gas emission. In our particular model we used GDP data nominated in USD and countries, to which local currencies were highly vulnerable during the analysed period (Ukraine, Belarus, Georgia, Moldavia), thus there were other determinants with more significant impact on GDP dynamics while industrial activity and following GHG emission were relatively stable.

The independent variable $G F C F$, as it could be assumed, also has to have a direct and positive impact on GHG emission: the more domestic investment the more production and pollution - according to pollution haven hypothesis. In this case, the crucial factor is the origin of investment. Post-soviet economies have less inner potential to accumulate resources and invest within periods of instability.

In comparison to previously mentioned variable, FDI inflow has statistically proved impact on GHG emission within our model. The achieved result suggests that a $1 \%$ rise of the foreign direct investment inflow entering the Baltic-Black Sea trans-national region countries in their economies, industrial sector would produce about a 0.146 $\%$ growth of GHG from fossil fuel consumption.

Also concluded to be significant ( $\mathrm{p}$-value $=0.035)$ and positive $(+0.002)$ is the relationship between sum of export and import of goods and service measured in \% of GDP (ExpImp) of the analysed economies and GHG emissions. Since this variable represents a level of economy's openness, we suggest that the more transparent and open economy to cooperation on international market, the more it has impact to the environment. In fact, a $1 \%$ growth of ExpImp variable generates about a $0.002 \%$ increase of GHG emissions per capita.

\section{Conclusions, Discussion and Recommendations}

In the frames of this work we focused our attention on the results mainly associated with the relationship between FDI inflow and GHG emission that we considered in our empirical estimation.

We observed a positive correlation between dependent and independent variables, when FDI variable was taken in the model as well as individually. In other words, both the OLS and random effects models show an interrelation pattern in the FDI-GHG relationship and highlight a damaging consequence of FDI to the environment.

The results also have shown statistically insignificant impact of GDP growth on GHG emission. This could be interpreted mostly as an exception to the rule, considering other determinants within a particular model.

The pollution haven hypothesis $(\mathrm{PHH})$ in the Baltic-Black Sea trans-national region countries policy in attraction of FDI has not been proved considering more strict high-standards environmental legislation in EU countries alongside with increase in GHG emission per capita. The main driver of this process was Poland, which has shown a significant growth of FDI and other macroeconomic indexes during analyzed period.

The aim of this study is to understand whether and how FDI inflow impacts the environment in terms of GHG emission. To this purpose and in accordance with the most recent literature, we built an equation model structured in such a way to consider dynamic effects of the FDI on the environmental variable. The model was analyzed by employing the econometric technique of panel data based on a dataset built on purpose and containing information for 8 Baltic-Black Sea trans-national region countries spanning 1999 through 2018. The results we achieved show that, in contrast to what would be assumed, FDI inflow has an impact on the environment, but it is severely limited by other more significant determinants.

Funding: self-funded.

Author Contributions: conceptualization, Moskalenko B.; methodology, Moskalenko B.; validation, Đonlagić A.; formal analysis, Moskalenko B.; investigation, Moskalenko B.; resources, Đonlagić A.; data curation, Đonlagić A.; writing original draft preparation, Moskalenko B.; writing review and editing, Đonlagić A.; visualization, Đonlagić A.; supervision, Đonlagić A.; project administration, Đonlagić A. 


\section{References}

1. Arellano M., Bover O. (1995). Another look at the instrumental variable estimation of error-components models. J Econom, 68(1), 29-51. Available at: https://doi.org/10.1016/0304-4076(94)01642-D.

2. Baier S.L., Bergstrand J.H. (2007). Do free trade agreements actually increase members' international trade? $J$ Int Econ, 71(1), 72-95. DOI: 10.1016/j.jinteco.2006.02.005.

3. Baier S.L., Bergstrand J.H., Feng M. (2014). Economic integration agreements and the margins of international trade. $J$ Int Econ, 93(2), 339-350. Available at: https://econpapers.repec.org/article/eeeinecon/v_3a93_3ay_3a2014_3ai_3a2_3ap_3a339-350.htm.

4. Blundell R., Bond S. (1998). Initial conditions and moment restrictions in dynamic panel data models. $J$ Econom, 87(1), 115-143. Available at: https://www.ucl.ac.uk/ uctp39a/Blundell-Bond-1998.pdf.

5. Bogdanova, O., \& Makarychev, A. (Eds.). (2020). Baltic-Black Sea Regionalisms. doi: 10.1007/978-3-03024878-9.

6. Cole M.A., Elliott R.J.R., \& Zhang L.Y. (2017). Foreign direct investment and the environment. In A. Gadgil \& T. P. Tomich (Eds.), Annual Review of Environment and Resources, 42, pp. 465-487. Available at: https://www.annualreviews.org/doi/abs/10.1146/annurev-environ-102016-060916.

7. Dunning, J. H. (2003). The eclectic (OLI) paradigm of international production: past, present and future International Business and the Eclectic Paradigm: Developing the OLI Framework (pp. 21-39). Doi: https://doi.org/10.1080/13571510110051441.

8. Erdogan A.M. (2014). Foreign direct investment and environmental regulations: a survey. J Econ Surv 28(5):943-955. Doi: https://doi.org/10.1111/joes.12047.

9. Galbraith, James (2007). Global inequality and global macroeconomics. Journal of Policy Modeling, 29 (4), 587-607. CiteSeerX 10.1.1.454.8135. doi: 10.1016/j.jpolmod.2007.05.008.

10. Grossman, G. M.; Krueger, A. B. (1991). Environmental impacts of a North American Free Trade Agreement. National Bureau of Economic Research Working Paper 3914, NBER. doi: 10.3386/w3914.

11. He, J., \& Richard, P. (2010). Environmental Kuznets curve for CO2 in Canada. Ecological Economics, 69(5), 1083-1093. Available at: https://econpapers.repec.org/article/eeeecolec/v_3a69 3ay_3a2010_3ai_3a5_3ap_3a1083-1093.htm.

12. Hille E. (2018). Pollution havens: international empirical evidence using a shadow price measure of climate policy stringency. Empir Econ 54(3):1137-1171. doi: https://doi.org/10.1007/s00181-017-1244-3.

13. Kok R., Ersoy B.A. (2009). Analyses of FDI determinants in developing countries. Int J Soc Econ, 36(1-2), 105-123. doi:https://doi.org/10.1108/03068290910921226.

14. Maddala, G. S., \& Wu, S. (1999). A comparative study of unit root tests with panel data and a new simple test. Oxford Bulletin of Economics and Statistics, 61(S1), 631-652. doi: https://doi.org/10.1111/1468$0084.0610 \mathrm{~s} 1631$.

15. Mohai, P., Pellow, D., \& Roberts, J. T. (2009). Environmental Justice. Annual Review of Environment and Resources, 34(1), 405-430. doi: 10.1146/annurev-environ-082508-094348.

16. Our World in Data (2019). $\mathrm{CO}_{2}$ and Greenhouse Gas Emissions. Our World in Data. Available at: https://ourworldindata.org/co2-and-other-greenhouse-gas-emissions.

17. Pazienza, P. (2015). The Environmental Impact of the FDI Inflow in the Transport Sector of OECD Countries and Policy Implications. International Advances in Economic Research, 21(1), 105-116. DOI: 10.1007/s11294-014-9511-y.

18. Porter G (1999) Trade competition and pollution standards: 'race to the bottom' or 'stuck at the bottom'? J Environ Dev, 8(2), 133-151. DOI: https://doi.org/10.1177/107049659900800203.

19. Rezza AA (2015) A meta-analysis of FDI and environmental regulations. Environ Dev Econ, 20(2), 185-208. DOI: https://doi.org/10.1017/s1355770x14000114.

20. Shahbaz M., Nasreen S., Afza T. (2011). Environmental consequences of economic growth and foreign direct investment: evidence from panel data analysis, MPRA Paper, no. 32547. Available at: http://mpra.ub.unimuenchen.de/32547/ last accessed 18th March 2013.

21. Stern, D. I. (2004a). The rise and fall of the environmental Kuznets curve. World Development, 32(8), 14191439. Available at: http://www.sterndavidi.com/publications_type.html. 
22. Stern, D. I. (2004b). Environmental Kuznets curve. In C. J. Cleveland (Ed.), Encyclopedia of energy (Vol. 2, pp. 517-525). San Diego: Academic. Available at: http://www.sterndavidi.com/publications type.html.

23. Taylor J (1999) Japan's global environmentalism: rhetoric and reality. Polit Geogr, 18(5), 535-562. Available at: https://doi.org/10.1016/S0962-6298(98)00112-7.

24. Wagner U.J., Timmins C.D. (2009) Agglomeration effects in foreign direct investment and the pollution haven hypothesis. Environ.Resour.Econ., 43(2), 231-256. DOI: https://doi.org/10.1007/s10640-008-9236-6.

25. Wooldridge, J. M. (2000). Econometric analysis of cross section and panel data. Cambridge: MIT Press Liang F.H. (2008). Does foreign direct investment harm the host country's environment? Evidence from China, social science research network (SSRN) research paper no. 1479864, pp. 1-29. Available at: http://ssrn.com/abstract=1479864 last accessed 14th December 2013.

26. World Bank (2019). World Development Indicators 2018. World Bank. Available at: https://data.worldbank.org/indicator.

27. Yaguchi, Y., Sonobe, T., \& Otsuka, K. (2007). Beyond the environmental Kuznets curve: a comparative study of SO2 and CO2 emissions between Japan and China. Environment and Development Economics, 12(3), 445470. DOI: $10.1017 / \mathrm{S} 1355770 \mathrm{X} 07003592$. 